\title{
ОСОБЛИВОСТІ ФОРМУВАННЯ ПСИХОЛОГІЧНИХ ЗАХИСНИХ МЕХАНІЗМІВ У СИТУАЦІЯХ СПІЛКУВАННЯ В ДІТЕЙ ПІДЛІТКОВОГО ВІКУ
}

Удк: $159.98: 316.77$

\section{Гончарук Наталія Миколаӥвна}

Кандидат психологічних наук, доиент, доиент кафедри загальної та практичної психології, Кам'янець-Подільський національний університет імені Івана Огієнка, м. Кам'янеиь-Подільський (Україна)

ORCID ID: orcid.org/0000-0001-9552-0946

\section{Онуфрієва Ліана Анатолївна}

\begin{abstract}
Кандидат психологічних наук, дочент, професор кафедри, завідувач кафедри загальної та практичної психологї, Кам'янець-Подільський національний університет імені Івана Огієнка, м. Кам'янеиь-Подільський (Украӥна)

ORCID ID: https://orcid.org/0000-0003-2442-4601
\end{abstract}

\begin{abstract}
Анотація. На підставі теоретичних досліджень обтрунтовано актуальність проблеми психологічного захисту для комунікативного розвитку особистості, описано понятійно-категоріальний апарат дослідження, представлено підходи до аналізу психологічних захисних механізмів, визначено основні функиї психологічного захисту, його різновиди та механізми.
\end{abstract}

Під час експериментального дослідження здійснено виявлення дітей підліткового віку 3 проблемами комунікації та експериментально досліджено їхні психологічні захисні механізми у ситуаціях спілкування. Науково обтрунтовано та диференційовано психологічні особливості формування захисних механізмів у підлітків, котрі не мають проблем у комунікації, та школярів 3 труднощами спілкування. Описано адаптивні стратегї дітей з різними особливостями комунікативного розвитку, від володіння якими залежить успіх міжособистісної взаємодї.

Доведено, щуо найбільш виразними у підлітків, у котрих не виявлено проблем комунікації, виявились такі психологічні захисти як проекиія, раціоналізація та заперечення. Найменш виразними були механізми компенсащії та гіперкомпенсащії. Виявлено, щзо у підлітків із проблемами комунікації психологічні захисти мають іншу природу: найбільш часто такі школярі 
використовують у спілкуванні захисні механізми регресіі, заперечення, заміщення $і$ витіснення. Водночас, найменш виразними, подібно до попередньої групи, також називаються прочеси компенсації та гіперкомпенсації.

За результатами експериментального дослідження визначено основні напрями формування ефективного психологічного захисту у дітей підліткового віку з комунікативними проблемами у розвитку та схарактеризовано систему поетапного психологічного впливу на підлітків із труднощами спілкування. Проведене дослідження дало змогу зробити висновки про необхідність розширеного та структурованого вивчення психологічних захисних механізмів, оскільки вони є основою формування ефективної комунікативної поведінки в дітей підліткового віку. Встановлено, щуо забезпечення необхідних змін у сфері спілкування створить підтрунтя для формування навичок успішної соціальної адаптації у системі комунікативної взаємодії.

Ключові слова: психологічний захист, психологічні захисні механізми, заміщення, витіснення, регресія, заперечення, раціоналізаџія, проекція, компенсація, гіперкомпенсація.

Постановка проблеми. Психологічний захист є функціонально необхідною психічною властивістю, яка сприяє зниженню емоційної напруги та звільненню від внутрішньоособистісних конфліктів. Його основною функцією є охорона від несприятливих впливів шляхом переструктурування свідомості на самопідтримку, самовиправдання чи інші самозахисні процеси, що сприяють зміцненню особистісної стабільності.

Незважаючи на актуальність проблеми психологічного захисту для розвитку особистості, ми не можемо говорити про достатню іiі розробленість. Психологічні дослідження, на сьогодні, є обмеженими та окреслюються, насамперед, межами психоаналітичних (3. Фрейд, А. Фрейд, К. Хорні) та екзистенційно-феноменологічних теорій (А. Ленгле, Ф. Перлз, К. Роджерс). Сучасні дослідження представлено роботами Л. Вассермана, О. Єришева, О. Клубової, В. Ветюгова, Р. Грановської, І. Нікольської, В. Соло- женкіна, Л. Субботіної, О. Чумакової, Т. Яценко. Водночас, психологічна практика потребує детального вивчення механізмів ефективного психологічного захисту, що сприятиме забезпеченню гармонійного емоційного розвитку, так і неефективного, що $є$ причиною дезадаптації особистості у соціумі.

У ситуаціях спілкування проблема психологічного захисту набуває особливої актуальності у підлітковому віці, оскільки це період активної міжособистісної комунікації. Емоційне неблагополуччя, виражене у високій тривожності та інших особистісних проблемax, є показником неуспішності психологічного захисту. Дослідження опірності школярів несприятливим соціальним впливам виявляє, що стихійно розвинені способи захисту є недостатньо ефективними у зв'язку з обмеженістю прийомів захисту, низьким рівнем їх усвідомленості, нездатності до вербалізації. Аналіз психологічної літератури показує, що відсутність психологічної готовності особистості 
до подолання психотравмуючих ситуацій виявляє негативний вплив на соціалізацію особистості у процесі спілкування (В. Ветюгов, 2008; О. Ковальова, 1998 [2; 4]). Це зумовлює необхідність психологічного навчання підлітків прийомам ефективного психологічного захисту.

Аналіз публікацій та досліджень. Розробка теоретичних та практичних аспектів проблеми психологічних захисних механізмів знайшла відображення у працях українських (I. Антоненко, Т. Горобець, Є. Карпенко, М. Кононова, В. Логвиненко, Л. Процик, Ю. Приходько, Т. Яценко та ін.) та зарубіжних вчених (Ж. Бержере, Е. Берн, Х. Келлерман, Х. Конте, Ж. Лапланш, Р. Плутчік, Ж.-Б. Понталис, А. Фрейд, 3. Фрейд та ін.). Останнім часом проблема набула особливої актуальності у дослідженнях науковців із близького зарубіжжя (Л. Анциферова, Т. Арістова, Ф. Бассін, М. Бурлакова, В. Волков, Р. Грановська, Л. Гребенніков, Ю. Кузіна, Р. Набіулліна, А. Налчаджян, І. Нікольська, Є. Романова, А. Соловйова, Л. Субботіна, Г. Тарт, Т. Тулуп'єва, І. Тухтарова та ін.).

\section{3 точки зору структурно-} функціональної організації психологічних захисних механізмів цю проблему розглядали Ф. Бассін, М. Бурлакова, В. Волков, Т. Горобець, Ю. Савенко, О. Соколова, Л. Субботіна. Генезис та функціонування психологічного захисту вивчали Є. Романова, Л. Гребенніков, Р. Грановська, I. Нікольска, В. Менінжер,
М. Ліф, А.Налчаджян, Г. Тарт. Порівняльні дослідження біологічних і психологічних їх компонентів здійснювала Т. Арістова. Адаптивний потенціал психологічного захисту досліджували I. Антоненко, С. Романова, Л. Гребенніков. Психоаналітичні розробки механізмів психологічного захисту проводили Ж. Бержере, Е. Берн, А. Фрейд, 3. Фрейд. На думку науковців, найбільш дослідженими на сьогодні $€$ такі механізми психологічного захисту як заперечення, витіснення, проекція, ідентифікація, раціоналізація, заміщення, відчуження $[1,9,11,12]$.

Особливості функціонування психологічних захисних механізмів у дитячому та підлітковому віці, сенситивному для розвитку спілкування, простежували О. Ковальова, А. Соловйова, Т. Тулуп'єва. 3 точки зору їх досліджень базовий спосіб захисту визначає патерни комунікативної поведінки дітей, які можуть бути соціально-бажаними, соціальнонейтральними або соціально-небажаними [5]. Важливим є використання психологічних захисних механізмів у систему дитячебатьківських взаємин. Психологічний захист особистості в системі дитяче-батьківської взаємодії аналізувала О. Чумакова, яка прийшла до висновку, що дитяча система психологічного захисту є гнучкою і має пристосувальний характер, на відміну від захисної поведінки дорослих. Тому важливим у дитячебатьківській взаємодії є відпрацювання ефективних та усунення неефективних механізмів 
психологічного захисту [10].

Механізми відпрацювання психологічного захисту досліджували Ж. Лапланш, Ж.Б. Понталіс. Засоби експлікації й утилізації захисних механізмів аналізували $Є$. В. Карпенко, В. Логвиненко; вплив патернів психологічного захисту на нормалізацію труднощів спілкування досліджували Л. Анциферова, Ф. Василюк, Ю. Кузіна, Р. Набіулліна, О. Руськіна, I. Тухтарова. Отже, з точки зору дослідників відпрацювання механізмів психологічного захисту має полягати в їх самоусвідомленні, цілемотиваційній спрямованості, самоорганізації, саморегуляції, посиленні відповідальності особистості, переосмисленні наявного досвіду для формування ефективних захисних моделей поведінки.

Досвід психологічної роботи у загальноосвітніх навчальних закладах засвідчує, що на сьогоднішній день не приділяється належна увага формуванню ефективної системи психологічного захисту дітей підліткового віку в умовах спілкування. Водночас ця психологічна робота є важливою, оскільки підлітковий період є сенситивним для розвитку комунікативних функцій. Саме у цьому віці необхідно формувати навички спілкування та, відповідно систему захисної комунікативної поведінки у складних ситуаціях стресу, тривоги, фрустрації. Виникає необхідність у проведенні спеціальних обстежень, спрямованих на виявлення особливостей функціонування психологічних захисних механізмів цієї вікової категорії дітей, розробку корекційних методів і прийомів роботи, які б сприяли формуванню позитивного досвіду спілкування. Це уможливить створення необхідних умов для адаптації підлітків до життя у соціумі.

Мета статті: визначити й науково обгрунтувати психологічні особливості формування психологічних захисних механізмів підлітків 3 проблемами комунікації у ситуаціях спілкування.

\section{Завдання статті:}

аналіз понятійно-категоріального апарату дослідження проблеми психологічних захисних механізмів;

виявлення дітей підліткового віку 3 проблемами комунікації;

експериментальне дослідження їхніх психологічних захисних механізмів у ситуаціях спілкування;

визначення напрямів впливу на систему психологічного захисту особистості.

Для розв'язання поставлених завдань використано такі методи теоретичного аналізу: порівняльний, системно-структурний аналіз, узагальнення, систематизацію; експериментального дослідження: спостереження за комунікативною діяльністю учнів; експертне оцінювання, аналіз результатів соціометрії Дж. Морено, методика «Індекс життєвого стилю» Р. Плучека, Г. Келлермана, Г. Конте, статистичне опрацювання даних.

Виклад основного матеріалу. Поняття психологічного захисту вперше виникло у 
психоаналітичній школі. Психоаналітики розглядали особистість як структуру, пов'язану 3 постійною боротьбою між «ід», основою якого є приховані потреби, та «суперего», яке передбачає соціальний контроль за реалізацією цих потреб. Взаємодія цих складових психіки передбачала наявність механізмів захисного характеру, щоб пригнічувати соціально заборонені потяги та потреби. Термін «психологічний захист» (англ. defense mechanism - механізм захисту) вводить 3. Фрейд, аналізуючи процеси витіснення, перенесення і сублімації. Пізніше феномен психологічного захисту детально вивчає донька i послідовниця великого психоаналітика А. Фрейд. Вона значно поповнює список різновидів захисту і доводить, що вони працюють не тільки проти заборонених потягів або фантазій, як вважає іiї батько, а й проти будьяких хворобливих станів, таких як стрес, фрустрація, депресія (А. Фрейд, 2009 [11]). У школярів ці стани зумовлено низьким рівнем навчальних досягнень, невмінням спілкуватись, конфліктами з однолітками, негараздами у сім'ї, розлученням батьків тощо.

У наукових дослідженнях психологічний захист пояснюється як вироблена в онтогенезі і притаманна будь-якій людині адаптивна стратегія несвідомого спотворення афективних і когнітивних аспектів тих ситуацій, які несуть загрозу сформованій картині світу (O. Чумакова, 1998), полісистемне утворення, яке має ієрархічну будову й охоплює перцептивні, емоційні, інструментально-процесуальні та соціальні характеристики, що забезпечують адаптивні форми поведінки (Л. Субботіна, 2006), процеси адаптації до кризових ситуацій, які знижують напруження, захищають від душевного болю або інших неприємних переживань (Р. Грановська, 1999), регулятивна система, спрямована на усунення почуття тривоги, пов'язаного з усвідомленням конфлікту (С. Головін, 2003) [3; 5; 7; 9].

У межах нашого дослідження психологічний захист пояснюється як адаптивна стратегія афективного чи когнітивного впливу на самосвідомість, яка дає змогу знизити напруження та захищає від негативних переживань. Він пов'язаний зі зміною внутрішніх цінностей особистості, спрямованою на зниження рівня суб'єктивної значимості переживань, що сприяє зведенню до мінімуму психотравмуючих моментів.

Основними функціями психологічного захисту є збереження «Я» від розпаду, досягнення потреби у самоповазі, отримання соціального схвалення, приховування від свідомості соціально неприйнятних мотивів і бажань (Е. Берн, 1964; В. Соложенкін, 2003; Л. Субботіна, 2006 [6; 7; 10]). Різновидами психологічних захисних механізмів $є$ витіснення, перенесення, сублімація, заперечення, витіснення, проекція, ідентифікація, раціоналізація, заміщення, відчуження (А. Фрейд, 2009; 3. Фрейд, 1990 [8; 11]).

У результаті вивчення стану розробле- 
ності проблеми спілкування як засобу реалізації психологічної захисної поведінки ми з'ясували, що воно передбачає використання ефективних адаптивних стратегій, від рівня володіння якими залежить успіх міжособистісної взаємодії. Поступово ці індивідуальні стратегії стають моделлю захисної поведінки, іiі індивідуальним стилем, який типово проявляється у різних комунікативних ситуаціях $\mathrm{i}$ виконує охоронну функцію обмеження особистості від несприятливого впливу соціуму.

Як показують результати теоретичного аналізу в осіб з різними психологічними особливостями, захисні механізми відрізняються. Особливо це стосується школярів з комунікативними особливостями поведінки, адже психологічні захисти проявляються, передусім, в ситуаціях спілкування. Це положення є суттєвим у роботі практичного психолога, оскільки передбачає використання різних підходів психологічного впливу. Психолог працює з дітьми, котрі мають психологічні проблеми, і йому важливо усвідомити специфіку перебігу їхніх захисних механізмів. Разом з тим, необхідно зрозуміти використання ефективних адаптивних стратегій, від рівня володіння якими залежить успіх міжособистісної взаємодіï.

Виходячи 3 цих теоретичних положень, було розроблено методику експериментального дослідження, яка включала два основних етапи: 1) виявлення дітей з проблемами комунікації шляхом спостереження за комунікати- вною діяльністю учнів (у спілкуванні з однолітками, вчителями); експертного оцінювання та аналізу результатів соціометрії Дж. Морено; 2) визначення провідних психологічних захисних механізмів у ситуаціях спілкування за методикою «Індекс життєвого стилю» (ІЖС) Р. Плутчика, Г. Келлермана, Г. Конте [1, с. 13]. Дослідження проводилось 3 дітьми підліткового віку, котрі вступали у період інтенсивної міжособистісної взаємодії й активно використовували психологічні захисні механізми у ситуаціях спілкування. Ним було охоплено 168 учнів 5-9 класів.

Перший eman включав відбір дітей 3 порушеннями у системі комунікації. За допомогою спостереження, експертного оцінювання та аналізу результатів соціометрії виявляли такі комунікативні проблеми: 1) сором'язливість - невпевненість у собі; ніяковість у спілкуванні з однолітками; 2) замкнутість - наявність аутичних проявів та мутизму, відсутність соціально спрямованої мотивації, небажання встановлювати емоційні контакти 3 іншими людьми; 3) конфліктність - схильність до конфронтації, несформованість навичок саморегуляції та самоконтролю у взаємодії з оточуючими, зайва принциповість та прямолінійність; 4) ізольованість у колективі однолітків - відсутність друзів, невміння налагоджувати емоційні контакти з однолітками, несформованість колективістських навичок, порушене відчуття групової належності; 5) під- 
вищена агресивність - часте вираження афекту $з$ негативним ставленням до оточуючих та нанесенням їм моральної чи фізичної шкоди, відсутність прийомів самоконтролю у спілкуванні, несформованість етичних форм поведінки, наявність негативізму

Таблиия 1.

Виявлення у 5-9 класах школярів 3 проблемами комунікації (дані подано у \%)

\begin{tabular}{|c|c|c|}
\hline Клас & $\begin{array}{c}\text { Діти з пробле- } \\
\text { мами } \\
\text { комунікації }\end{array}$ & $\begin{array}{c}\text { Діти, у котрих } \\
\text { не виявлено } \\
\text { проблем кому- } \\
\text { нікації }\end{array}$ \\
\hline 5-А клас & $33,3 \%$ & $66,7 \%$ \\
\hline $5-$ клас & $35,7 \%$ & $64,3 \%$ \\
\hline 6 клас & $44,4 \%$ & $55,6 \%$ \\
\hline 7 клас & $42,9 \%$ & $57,1 \%$ \\
\hline 8 клас & $42,9 \%$ & $57,1 \%$ \\
\hline 9 клас & $39,9 \%$ & $60,1 \%$ \\
\hline Всього & $39,9 \%$ & $60,1 \%$ \\
\hline
\end{tabular}

як опозиційної манери поведінки; 6) недисциплінованість та імпульсивність поведінки - відсутність навичок вольового контролю, безвідповідальність та легковажність, невміння передбачати наслідки спілкування, прогнозувати потенційно негативні та небезпечні ситуації, схильність до ризику.

Вивчення у дітей підліткового віку особливостей спілкування здійснювалось у порівняльному аспекті. Для порівняння використовувались дві групи - школярі з психологічними проблемами комунікації та учні, у котрих не виявлено порушень. Для з'ясування наявності комунікативних проблем викорис- товували спостереження, експертне оцінювання та аналіз результатів планової соціометрії. У результаті застосування описаних методів 3'ясовано, що у 5-9 класах виявлено значну кількість дітей, котрі мають різноманітні комунікативні проблеми психологічного характеру, про що свідчать дані Таблиці 1. Вони показують, що у кожному класі кількість таких дітей коливається від 9 до 12 учнів.

Пропорційність відношення дітей з комунікативними проблемами до загальної кількості учнів можна простежити на діаграмі (Рис. 1.)

Як свідчать дані експериментальних досліджень у 5-9 класах кількість дітей 3 проблемами комунікації коливається від $33,3 \%$ до 44,4\%. Це досить високий показник, який дає змогу зробити припущення про несприятливі особливості психоемоцій-

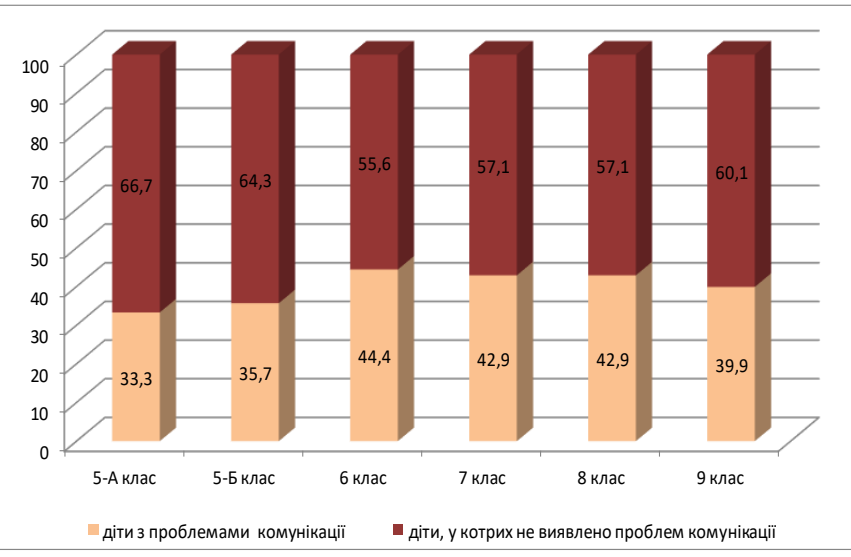

Рисунок 1. Розподіл школярів за наявністю психологічних проблем комунікації (дані подано у \%)

ного стану значної частини дітей.

Розподіл учнів за наявністю психоло- 
гічних проблем можна простежити за допомогою Таблиці 2 та Діаграми 2.

Дані таблиці свідчать, що серед усього
$(60,1 \%)$ відноситься до категорії дітей, котрі не мають психологічних проблем у розвитку. Серед тих, хто їх має, зустрічаються

Таблиия 2.

Аналіз психологічних проблем комунікації у дітей підліткового віку (дані подано у \%)

\begin{tabular}{|c|c|c|c|}
\hline № & Психологічні проблеми комунікації & $\begin{array}{c}\text { К-ть } \\
\text { дітей }\end{array}$ & \% \\
\hline 1. & Сором'язливість & 18 & $10,7 \%$ \\
\hline 2. & Замкнутість & - & $0,0 \%$ \\
\hline 3. & Конфліктність & 14 & $8,3 \%$ \\
\hline 4. & Ізольованість у колективі однолітків & 20 & $11,9 \%$ \\
\hline 5. & Підвищена агресивність & 16 & $9,5 \%$ \\
\hline 6. & Недисциплінованість та імпульсивна поведінка & 33 & $19,6 \%$ \\
\hline 7. & Відсутність комунікативних проблем & 101 & $60,1 \%$ \\
\hline & Всього & $\mathbf{1 6 8}$ & $\mathbf{1 0 0 , 0 \%}$ \\
\hline
\end{tabular}

переліку психологічних проблем комунікації найбільше дітей $(19,6 \%)$ проявляють недисциплінованість та імпульсивну поведінку. Це пов’язано з віковими особливостями підлітків, для котрих характерно недостатність вольових зусиль та висока психорухова активність порівняно $з$ дорослими. Також часто спостерігається ізольованість у колективі однолітків $(11,9 \%)$ та сором'язливість (10,7\%). Потрібно відмітити, що серед усіх перерахованих психологічних проблем взагалі не зустрічається замкнутості. Це пов'язано з клінічним походженням цієї проблеми, що нетипово для школи, де навчаються діти зі збереженим психічним здоров'ям.

Розподіл психологічних проблем комунікації порівняно з середньостатистичною нормою можна простежити за діаграмою (Рис. 2).

Як бачимо, найбільше школярів

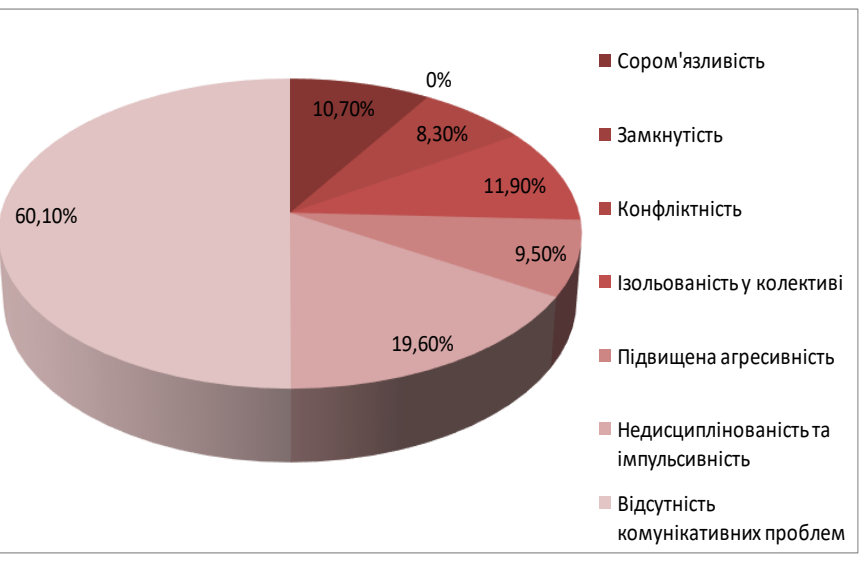

Рисунок 2. Розподіл дітей підліткового віку за особливостями комунікативної проблематики (дані подано у \%)

учні (у порядку від найбільшого \%): з недисциплінованістю та імпульсивністю $(19,6 \%)$, ізольованістю у колективі однолітків $(11,9 \%)$, сором'язливістю $(10,7 \%)$, підвищеною агресивністю $(9,5 \%)$ та конфліктністю (8,3\%). Це свідчить, що проблеми у комунікативному розвитку характерні для значної частини школярів підліткового віку 
(39,9\%). Ці категорії потребують допомоги практичного психолога у формуванні навичок спілкування.

Другим етапом експериментального дослідження було з'ясування провідних захисних механізмів, які використовували підлітки першої та другої групи. 3 цією метою проводили методику «Індекс життєвого стилю» Р. Плутчика, Г. Келлермана, Г. Конте, за допомогою якої вивчали психологічні захисні механізми особистості у ситуаціях спілкування. Під час експерименту досліджували такі різновиди психологічного захисту: 1) заміщення - перенесення дії $з$ недосяжного на досяжний об'єкт; 2) витіснення - винесення за сферу свідомості болісних переживань; 3) регресію - повернення на менш зрілу стадію розвитку особистості; 4) заперечення відмову визнати інформацію, яку важко прийняти; 5) раціоналізацію - прагнення обгрунтувати неконструктивні діï; 6) проекцію - приписування оточуючим власних мотивів поведінки; 7) компенсацію подолання особистісних вад шляхом розвитку інших якостей; 8) гіперкомпенсацію - прагнення перебороти негаразди шляхом надмірного розвитку однієї риси або здібності, що дозволяє зайняти домінуючу позицію стосовно інших (див. Табл. 3).

Як бачимо з таблиці, у 30,2 \% дітей, у котрих не виявлено проблеми комунікації, найвищий показник спостерігається за шкалою «проекція» — приписування іншим влас- них мотивів поведінки. Школярі, котрі використовують цей механізм захисту у напружених ситуаціях спілкування, власні несвідомі риси, спонукання, мотиви приписують іншим, проектуючи на них свою поведінку. Також високий показник спостерігається за шкалою «заперечення» $(21,8$ \% учнів) - неприйнятні думки, бажання, факти, вчинки підлітки відмовляються приймати на свій рахунок. 18,5 \% учнів схильні до раціоналізації у своїх вчинТаблиия 3.

Результати проведення методики ІЖС Р. Плутчика, Г. Келлермана, Г. Конте для вивчення різновидів психологічного захисту

\begin{tabular}{|c|c|c|c|}
\hline \multirow{2}{*}{$\begin{array}{c}\text { № } \\
\text { 3/п }\end{array}$} & $\begin{array}{c}\text { Різновиди } \\
\text { пахогічного }\end{array}$ & $\begin{array}{r}\text { Виразність механізмів психо- } \\
\text { логічного захисту } \\
\text { (дані подано у \%) }\end{array}$ \\
\cline { 3 - 4 } & $\begin{array}{c}\text { У дітей, в } \\
\text { котрих не } \\
\text { виявлено } \\
\text { проблем } \\
\text { комунікації }\end{array}$ & $\begin{array}{c}\text { У дітей } 3 \\
\text { проблемами } \\
\text { комунікації }\end{array}$ \\
\hline 1 & Заміщення & $8,4 \%$ & $13,4 \%$ \\
\hline 2 & Витіснення & $6,7 \%$ & $11,8 \%$ \\
\hline 3 & Регресія & $8,4 \%$ & $26,9 \%$ \\
\hline 4 & Заперечення & $21,8 \%$ & $23,5 \%$ \\
\hline 5 & Раціоналізація & $18,5 \%$ & $7,2 \%$ \\
\hline 6 & Проекція & $30,2 \%$ & $8,4 \%$ \\
\hline 7 & Компенсація & $3,4 \%$ & $5,0 \%$ \\
\hline 8 & Гіперкомпен- \\
сація & $3,4 \%$ & $5,0 \%$ \\
\hline
\end{tabular}

ках. Вони намагаються пояснювати свою неконструктивну поведінку раціональним чином, виявляючи прагнення до самовиправдання.

Найменш виразними у підлітків, у котрих не виявлено проблем комунікації, вияви- 
лись такі психологічні захисти як компенсація $(3,4 \%)$ та гіперкомпенсація $(3,4 \%)$. Це свідчить, що ці учні рідко формують механізм заміщення фізичної або психічної неповноцінності шляхом розвитку інших якостей та не прагнуть досягнути успіху і значущості в тій області, яка є для них найбільш складною.

Співвідношення психологічних захис- прийняти; переносять дії 3 недосяжного на досяжний об'єкт; намагаються винести за сферу свідомості болісні переживання.

Найбільш частими у них $є$ механізми регресії та заперечення. Заперечення, як спосіб захисту, характеризується спростованим сприйманням дійсності. Для його використання властивим $є$ те, що емоційно уразлива ін-

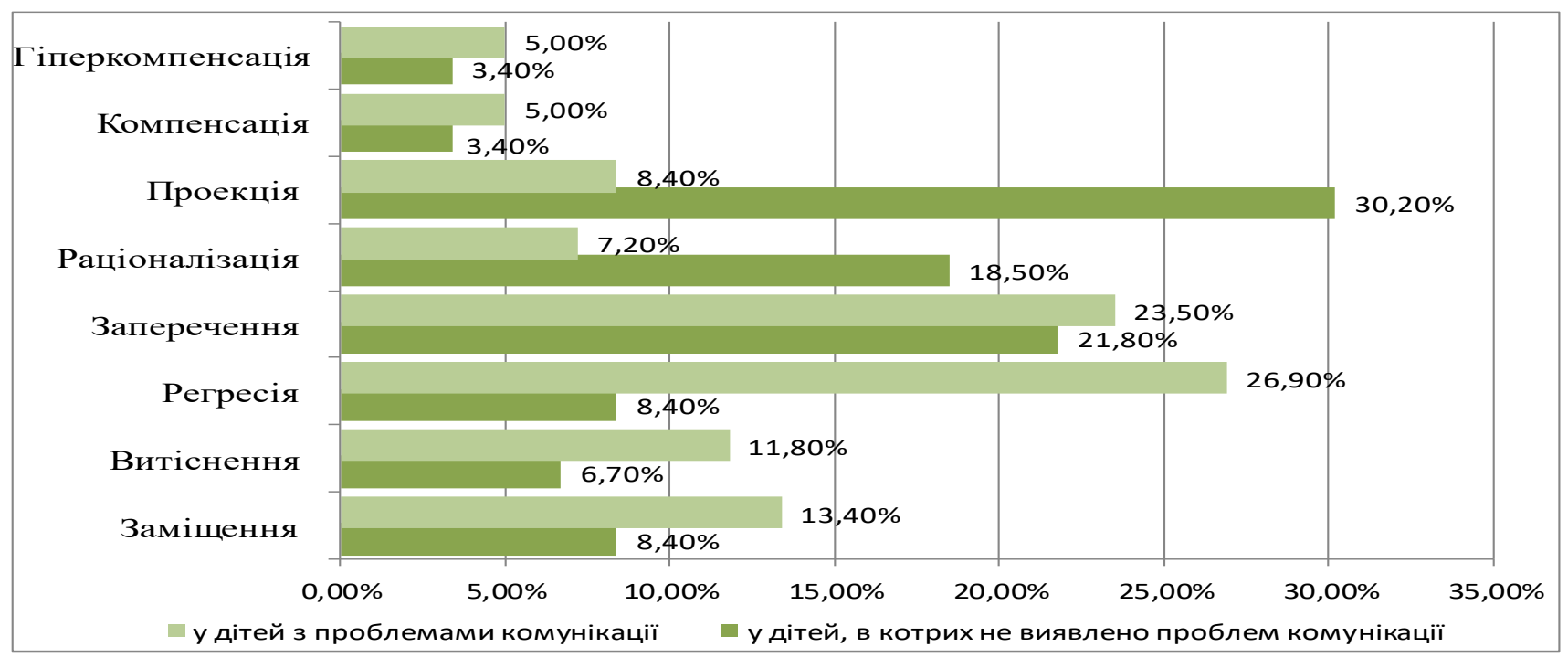

Рисунок 3. Співвідношення психологічних захисних механізмів у дітей 3 проблемами комунікації та дітей, у котрих не виявлено проблем комунікації

них механізмів можна простежити за Рис. 3.

Водночас, дані експериментального дослідження демонструють, що у підлітків 3 проблемами комунікації психологічні захисти мають іншу природу. Зокрема, найбільш часто такі школярі використовують у спілкуванні захисні механізми регресії (26,9 \%), заперечення $(23,5 \%)$, заміщення $(13,4 \%)$ і витіснення (11,8 \%). Це вказує на те, що у спілкуванні вони вдаються до повернення на менш зрілу стадію розвитку особистості; часто відмовляються визнати інформацію, яку важко формація відкидається та ігнорується. Заперечення не дає змоги дітям адекватно оцінювати події довкола, що призводить до труднощів у поведінці. Регресія є поверненням до ранніх інфантильних форм поведінки. Вона проявляється в емоційному реагуванні, схильності до капризування, загостреному почутті провини. Підлітки з регресивними формами поведінки більш схильні до підпорядкування, ніж до управління взаємостосунками.

Найменш виразними у дітей є процеси компенсації (5,0 \%) та гіперкомпенсації 
(5,0\%). Це свідчить, що підлітки з психологічними проблемами у спілкуванні не прагнуть досягати результатів шляхом розвитку інших якостей і не ставлять за мету отримувати успіх в найбільш складній для них сфері. Зазвичай, низькі показники за цими різновидами психологічних механізмів мають діти 3 несформованими вольовими якостями особистості.

Висновки. Проведене теоретичне та експериментальне дослідження психологічних захисних механізмів у ситуаціях спілкування в дітей підліткового віку дає змогу зробити такі висновки:

Кількість дітей 3 проблемами $\mathrm{y}$ спілкуванні коливається від 33,3\% до 44,4\% у різних класах. Це високий показник, який свідчить про несприятливі особливості комунікативної взаємодії у значної частини дітей. Серед усього переліку психологічних проблем комунікації найчастіше спостерігаються імпульсивна поведінка, ізольованість у колективі однолітків, сором'язливість. Діти 3 проблемами комунікації надають перевагу використовувати у спілкуванні захисні механізми регресії, заперечення, заміщення і витіснення.

Підлітки, у котрих не виявлено проблеми комунікації, найчастіше вдаються до захисних механізмів проекції, заперечення та раціоналізації, що свідчить про прагнення приписувати іншим мотиви своєї поведінки, відмову приймати на свій рахунок неприйнятні дії та вчинки, намагання пояс- нювати свою неконструктивну поведінку раціональним чином.

Дані експериментального дослідження дали змогу визначити основні напрями формування ефективного психологічного захисту у дітей підліткового віку 3 комунікативними проблемами у розвитку. До них відносяться: a) самодіагностика комунікативної поведінки та психологічна просвіта, яка передбачає ознайомлення підлітків 3 основними різновидами психологічного захисту у ситуаціях спілкування; б) використання ефективних механізмів психологічного захисту, які дають змогу досягати соціально бажаних результатів діяльності; в) аналіз неефективних психологічних захистів та зниження їх інтенсивності; г) формування високого рівня та балансу раціональної поведінки у спілкуванні.

\section{Перспективи подалыших досліджень.} Дослідження психологічних захисних механізмів має широкі перспективи у плані формування ефективної комунікативної поведінки в дітей підліткового віку. Перспективою подальших досліджень $є$ визначення психологічних умов, створення та експериментальна апробація комунікативних технологій формування конструктивного психологічного захисту, який створить можливості для успішної адаптації у системі соціальних взаємин.

\section{Перелік використаних джерел:}

1. Берн Е. Игры, в которые играют люди: Психология человеческих взаимоотношений. Люди, которые 
играют в игры: Психология человеческой судьбы : пер. с англ. / Э. Берн; [общ. ред. М.С.Мацковского]. - СПб. ; М. : Университет. кн., 1998. - 398 с.

2. Вассерман Л. И. Психологическая диагностика индекса жизненного стиля / Л. И. Вассерман, О. Ф. Ерышев, Е. Б. Клубова. - Спб. : СПбНИПНИ им. В.М.Бехтерева, 2005. - $50 \mathrm{c}$.

3. Ветюгов В. В. Психологические защиты у девочекподростков, злоупотребляющих психоактивными веществами : дисс. ... канд. мед. наук : 19.00 .04 / В. В. Ветюгов. - М., 2008. - 201 с.

4. Грановская Р. М. Защита личности: психологические механизмы / Рада Михайловна Грановская, Ирина Михайловна Никольская. - СПб. : Знание, 1999. - 352 с.

5. Ковалёва E. Б. Способы психологической защиты детей старшего дошкольного возраста с повышенной тревожностью и их коррекция : дисс. ... канд. психол. наук : 19.00.07 / Е. Ковалёва. - Иркутск, 1998. - 172 с.

6. Словарь практического психолога / [сост. С.Ю.Головин]. - Минск : Харвест, 2003. - 800 с.

7. Соложенкин В. В. Психологические основы врачебной деятельности : учебн. / В. В. Соложенкин. - М. : Академический проект, 2003. - 304 с.

8. Субботина Л. Ю. Структурно-функциональная организация психологиче-ской защиты личности : дисс. ... докт. психол. наук : 19.00.03 / Лариса Субботина. - Ярославль, 2006. - 318 с.

9. Фрейд 3. Психология бессознательного : сб. произведений / 3. Фрейд; [сост., науч. ред., авт. вступ. ст. М.Г. Ярошевский]. - М. : Просвещение, 1990. - 448 с.

10. Чумакова E. В. Психологическая защита личности в системе детско-родительского взаимодействия : дисс. ... канд. психол. наук : 19.00.11 / Елена Чумакова. СПб. : СПГУ, 1998. - 184 с.

11. Bern E. Games People Play: The Psychology of Human Relationships / E. Bern. - New York : Grove Press, 1964.

12. Freud A. Theory and Practice in Child Psychoanalysis / [edited by G. Hall, F.Hivernel, S. Morgan]. - London : Karnac Books, 2009. - 224 p.

\section{References (Transliteration):}

1. Bern E. Igry, v kotorye igrajut ljudi: Psihologija chelovecheskih vzaimootnoshenij. Ljudi, kotorye igrajut $\mathrm{v}$ igry: Psihologija chelovecheskoj sud'by : per. s angl. / Je. Bern; [obshh. red. M.S.Mackovskogo]. - SPb. ; M. : Universitet. kn., 1998. - 398 s.

2. Vasserman L. I. Psihologicheskaja diagnostika indeksa zhiznennogo stilja / L. I. Vasserman, O. F. Eryshev, E. B. Klubova. - Spb. : SPbNIPNI im. V.M.Behtereva, 2005. $50 \mathrm{~s}$.

3. Vetjugov $V$. V. Psihologicheskie zashhity u devochekpodrostkov, zloupotrebljajushhih psi-hoaktivnymi veshhestvami : diss. ... kand. med. nauk : 19.00.04 / V. V. Vetjugov. - M., 2008. - 201 s.

4. Granovskaja R. M. Zashhita lichnosti: psihologicheskie mehanizmy / Rada Mihajlovna Granovskaja, Irina Mihajlovna Nikol'skaja. - SPb. : Znanie, 1999. - 352 s.

5. Kovaljova E. B. Sposoby psihologicheskoj zashhity detej starshego doshkol'nogo vozrasta s povyshennoj trevozhnost'ju i ih korrekcija : diss. ... kand. psihol. nauk : 19.00.07 / E. Kovaljova. - Irkutsk, 1998. - 172 s.

6. Slovar' prakticheskogo psihologa / [sost. S.Ju.Golovin]. Minsk : Harvest, 2003. - 800 s.

7. Solozhenkin V. V. Psihologicheskie osnovy vrachebnoj dejatel'nosti : uchebn. / V. V. Solozhenkin. - M. : Akademicheskij proekt, 2003. - 304 s.

8. Subbotina L. Ju. Strukturno-funkcional'naja organizacija psihologiche-skoj zashhity lichnosti : diss. ... dokt. psihol. nauk : 19.00.03 / Larisa Subbotina. - Jaroslavl', 2006. - 318 s.

9. Frejd Z. Psihologija bessoznatel'nogo : sb. proizvedenij / Z. Frejd; [sost., nauch. red., avt. vstup. st. M.G. Jaroshevskij]. - M. : Prosveshhenie, 1990. - 448 s.

10. Chumakova E. V. Psihologicheskaja zashhita lichnosti v sisteme detsko-roditel'skogo vza-imodejstvija : diss. ... kand. psihol. nauk : 19.00.11 / Elena Chumakova. - SPb. : SPGU, 1998. - $184 \mathrm{~s}$.

11. Bern E. Games People Play: The Psychology of Human 
Relationships / E. Bern. - New York : Grove Press, 1964.

12. Freud A. Theory and Practice in Child Psychoanalysis / [edited by G. Hall, F.Hivernel, S. Morgan]. - London : Karnac Books, 2009. - 224 r.

\section{Honcharuk Nataliia}

Ph. D. in Psychological Sciences, Assistant Professor, Assistant Professor of the Department of General and Practical Psychology, Kamyanets-Podilsky Ivan Ohienko National University, Kamianets-Podilskyi (Ukraine)

\section{Onufriieva Liana}

Ph. D. in Psychological Sciences, Assistant Professor, Professor of the Department of General and Applied Psychology, Head of the Department of General and Applied Psychology, Kamyanets-Podilsky Ivan Ohienko National University, Kamianets-Podilskyi (Ukraine)

\section{THE FEATURES OF PSYCHOLOGICAL PROTECTIVE MECHANISMS FORMATION IN COMMUNICATION SITUATIONS AMONG TEENAGERS}

\section{ABSTRACT}

On the basis of theoretical research the relevance of the problem of psychological protection for the personality's communicative development is proved, the conceptual and categorical apparatus of the research is described, the approaches to the analysis of psychological protective mechanisms are presented, the basic functions of psychological defense, its variants and mechanisms are defined.

During the pilot study, teenage children with problems on communication were identified and their psychological protective mechanisms in communication situations were experimentally investigated. There are scientifically proved and differentiated the psychological peculiarities of the formation of teenagers' protective mechanisms without any problems in communication, and pupils with difficulties in the intercourse. The adaptive strategies of children with different peculiarities of communicative development are described, and the success of interpersonal interaction depends on their possession.

It has been proved that the most expressive psychological protections of teenagers without any communication problems were the following: projection, rationalization and negation. The least expressive mechanisms were the compensation and hypercompensation. It has been found that the psychological protections of teenagers with communication problems have a different nature: these schoolchildren more often use communication mechanisms of regression, negation, substitution and displacement. At the same time, the least expressive, like the previous group, are the compensation and hypercompensation processes.

On the basis of the experimental research, the main directions of the effective psychological protection formation of teenagers with communicative problems in development are determined. The system of phased psychological influence on teenagers with communication difficulties is described.

The conducted study made it possible to draw conclusions about the need for an expanded and structured study of psychological protective mechanisms, since they are the basis for the formation of effective communicative behavior of teenagers. It has been established that providing necessary changes in the field of communication 
would create the basis for the formation of skills of successful social adaptation in the system of communicative interaction.

Key words: psychological defense, psychological protective mechanisms, replacement, displacement, regression, negation, rationalization, projection, compensation, hypercompensation.

\section{Гончарук Наталия Николаевна}

Кандидат психологических наук, доиент, доиент кафедры общей и практической психологии, КаменечПодольский начиональный университет имени Ивана Огиенко, г. Каменец-Подольский (Украина)

\section{Онуфриева Лиана Анатольевна}

Кандидат психологических наук, доиент, профессор кафедры, заведующий кафедрой общей и практической психологии, Каменец-Подольский начиональный университет имени Ивана Огиенко, г. Каменец-Подольский, (Украина)

\section{ОСОБЕННОСТИ ФОРМИРОВАНИЯ ПСИХОЛОГИЧЕСКИХ МЕХАНИЗМОВ В СИТУАЦИЯХ ОБЩЕНИЯ У ДЕТЕЙ ПОДРАСТКОВОГО ВОЗРАСТА}

Аннотация. На основании теоретических исследований обоснована актуальность проблемы психологической защиты для коммуникативного развития личности, описан понятийно-категориальный аппарат исследования, представлены подходы к анализу психологических защитных механизмов, определены основные функции психологической защиты, её разновидности и механизмы.

Во время экспериментального исследования осуществлено выявление детей подрасткового возраста с проблемами коммуникации и экспериментально исследованы их психологические защитные механизмы в ситуациях общения. Научно обоснованы и дифференцированы психологические особенности формирования защитных механизмов у подростков, которые не имеют проблем в коммуникации, и школьников с трудностями общения. Описаны адаптивные стратегии детей с различными особенностями коммуникативного развития, от обладания которыми зависит успех межличностного взаимодействия.

Доказано, что наиболее выразительными у подростков, у которых не выявлено проблем коммуникации, оказались такие психологические защиты как проекция, рационализация и возражения. Наименее выразительными были механизмы компенсации и гиперкомпенсации. Выявлено, что у подростков с проблемами коммуникации психологические защиты имеют другую природу: наиболее часто такие школьники используют в общении защитные механизмы регрессии, отрицание, замещение и вытеснение. В то же время, наименее выразительными, подобно предыдущей группе, также оказываются процессы компенсации и гиперкомпенсации.

На основании экспериментального исследования определены основные направления формирования эффективной психологической защиты у детей подросткового возраста с коммуникативными проблемами в развитии и дана характеристика системе поэтапного психологического воздействия на подростков с 
трудностями общения.

Ключевые слова: психологическая защита, психологические защитные механизмы, вытеснение, регрессия, отрицание, рационализация, проекция, компенсация, гиперкомпенсация.

Дата отримання статті: 13.06 .2018 Дата рекомендації до друку: 17.06.2018 Дата оприлюднення: 02.07.2018 